\title{
Localization of insulin immunpositive cells and histochemical structure of the pancreas in falcons (Falco Anaumanni)
}

\author{
Nejdet ŞİMŞEK ${ }^{1}$, A.Gürol BAYRAKTAROĞLU², Hikmet ALTUNAY ${ }^{3}$ \\ ${ }^{1}$ Department of Histology and Embryology, Faculty of Veterinary Medicine, University of Atatürk, Erzurum; ${ }^{2}$ Department of \\ Histology and Embryology, Faculty of Veterinary Medicine, University of Ankara, Ankara; ${ }^{3}$ Department of Histology and \\ Embryology, Faculty of Veterinary Medicine, University of Mehmet Akif Ersoy, Burdur, Turkey
}

\begin{abstract}
Summary: The present study was conducted to determine the regional distribution of insulin immunpositive cells and histochemical structure of pancreas in falcon (Falco Anaumanni). Falcon pancreas was composed of three different parts as dorsal, ventral and splenic lobes. Those lobes contained acinar cells, pancreatic ducts, alpha, beta and mixed islets. Alpha islets were determined 3-4 unit as large islets in centre of the splenic lobe, but a few as small islets in dorsal and ventral lobes. Beta islets were widespread as small clusters in all lobes which were especially 7-8 units in periphery of the splenic lobe. Furthermore, mixed islets were found abundantly as small or large islets in all lobes. In the streptavidin biotin peroxidase staining of the pancreatic lobes, insulin immunpositive cells were numerous in the centre of beta islets, on the other hand these cells were detected as only one cell or 3-8 immunpositive cell groups in both alpha islets and exocrine tissue. In conclusion, the morphology and insulin immunpositive cells of pancreas in falcons are similar to duck, whereas are different from other avian species such as chicken, goose, and quail.

Key words: Falcon, immunohistochemistry, insulin immunpositive cells, pancreas.
\end{abstract}

\section{Şahinlerde (Falco Anaumanni) pankreasın histokimyasal yapısı ve insülin immunpozitif hücrelerin lokalizasyonu}

\begin{abstract}
Özet: Bu çalışma, şahin (Falco Anaumanni) pankreasının histokimyasal yapısı ve insülin immunpozitif hücrelerin bölgesel dağılımını belirlemek için yapıldı. Şahin pankreası dorsal, ventral ve dalak lobu olarak 3 farklı lobdan oluşuyordu. Bu loplar asiner hücreler, akıtıcı kanallar, alfa, beta ve mix adacıkları içermekteydi. Alfa adacıkları dalak lobunun merkezinde 3-4 adet büyük adacık halinde gözlenirken, dorsal ve ventral lopta az sayıda küçük adacıklar halinde belirlendi. Beta adacıkları özellikle dalak lobunun periferinde 7-8 adet küçük adacıklar halinde bütün loplarda çok sayıda tespit edildi. Ayrıca, miks adacıklarının küçük ya da büyük adacıklar halinde pankreasın bütün loplarında çok yaygın bir şekilde bulunduğu saptandı. Pankreatik lobların streptavidin-biotin peroksidaz boyamalarında, insulin immunpozitif hücreler beta adacıkları merkezinde çok sayıdaydı diğer yandan bu hücreler hem alfa adacıklarında hem de ekzokrin dokuda yalnız tek bir hücre ya da 3-8 hücrelik gruplar halinde görüldü. Sonuç olarak şahin pankreasının morfolojik ve insulin pozitif hücreler açısından ördek pankreası ile benzer olduğu, tavuk, kaz ve bıldırcın gibi diğer kanatlı türlerinin pankreaslarından farklı olduğu tespit edilmiştir.

Anahtar sözcükler: İmmunhistokimya, insulin pozitif hücreler, pancreas, şahin.
\end{abstract}

\section{Introduction}

The pancreas is an important mixed gland associated with the gastrointestinal system. It lies retroperitoneally that is comprised of head, body and tail regions in the mammalians. The head lies in the $\mathrm{C}$ shaped region of the duodenum, the body and tail extend across the posterior wall of the abdomen toward the hilum of the spleen. The bird's pancreas is comprised of dorsal, ventral and splenic lobes, which are positioned between the ascending and descending loops of the duodenum (19). Moreover, quail pancreas is containing of third lobe positioned between dorsal and ventral lobes, but neighbor with the descending loop of the duodenum (24). The pancreas is composed of exocrine and endocrine compartment; the exocrine tissue, which secretes pancreatic digestive juice, and the endocrine tissue, which secretes the hormones insulin, glucagons, somatostatin and pancreatic polypeptide for the control of the carbohydrate metabolism $(12,16)$.

The exocrine pancreas is formed by acinar cells and excretory ducts with small and large diameter. The cytoplasm of the acinar cells is richer in point of view of rough endoplasmic reticulum (ER), mitochondria of the crista type, free ribosomes, and secretory zymogene granules (16). Centro-acinar cells have euchromatic nucleus which are found towards the lumina of acini which produce fluid rich in sodium and bicarbonate. Pancreatic juice empties from highly branched duct system into the duodenum via the ampulla of Vater (8). In birds, the main excretory ducts are consisted of the 
dorsal and ventral pancreatic ducts (4). Moreover, some avian species have an additional third duct (24).

The endocrine pancreas of the mammals is comprised by islets of Langerhans which is distributed throughout the exocrine pancreas, and found more numerous in the tail lobe than other lobes. These islets are formed by alpha $\left(\mathrm{A}, \mathrm{A}_{2}, \alpha\right)$, beta $(\mathrm{B}, \beta)$, delta $(\mathrm{D}, \delta$, $\mathrm{A}_{1}$ ) and pancreatic polypeptide (PP, F) cells. The insulin and glucagon hormones produce in the greatest amounts by beta and alpha cells which decrease and increase blood glucose levels, respectively. D cells release somatostatin which inhibit the release of glucagon and insulin hormones, but pancreatic polypeptide hormone produced by PP cells inhibits the exocrine pancreas secretions $(10,12,14,15,19)$. The endocrine pancreas of the fowl is make up of small and large islets called alpha, beta and mixed islets $(5,14)$. Alpha islets are found in great numbers in the caput region of the splenic lobe and third lobe (25), which are composed of alpha, beta and D cells in chickens (11) and young quails (24). Beta islets that are numerous in all lobes, are composed of beta and $\mathrm{D}$ cells in chickens (25), whereas beta, alpha and D cells in geese (10) and young quails (24).

The aim of this study was to determine morphological, histochemical and immunohistochemical of the exocrine and endocrine pancreas by light microscopic examination in falcons (Falco Anaumanni).

\section{Materials and Methods}

Animals and histochemical procedures: Nonreleasable, but healthy five predatory falcons were received from General Directorate of Nature Protection and National Parks (Ankara/Turkey) with animal hospital in Veterinary Medicine (P.No: 2008-59, Erzurum/ Turkey). The falcons were sacrificed under ether anaesthesia and their pancreases were divided into the dorsal, ventral and splenic lobe. Tissue samples taken from the pancreas were fixed (18 hours) in Bouin's and neutral buffered formalin fixative fluids for immunohistochemical and histochemical examination. The fixed materials were dehydrated in a graded series of ethanol, and embedded in paraplast. Four to five-micrometer $(\mu \mathrm{m})$ thick 5 unit serial sections cut from tissue blocks were applied Mallory's triple stain modified by Crossman in order to determine the general structure of the organ, aldehyde fuchsin (AF) staining in order to determine the distribution of alpha, beta and mixed islets (1).

Immunohistochemical procedures: Insulin releasing cells were detected by immunohistochemistry using the streptavidin-biotin-peroxidase method (DAKO-Universal LSAB Kit-K0690) and 3,3'-diaminobenzidine tetrahydrochloride (DAB, SIGMA-D5905, 50 tablet) to detect peroxidase activity (17). For streptavidin-biotinperoxidase staining method, tissue samples were deparaffinized in xylene and rehydrated through a decreasing series of ethanol. Then, these sections were incubated with $3 \% \mathrm{H}_{2} \mathrm{O}_{2}$ in order to block endogenous peroxidase activity and with normal bovine serum for blocked nonspecific binding sites of antibodies. The following primary antibody (anti-insulin IgG -dilution: 1/150-Polyclonal Guinea Pig Anti-Swine Insulin, DAKO-A0564) and biotinylated secondary antibody (DAKO-Universal LSAB Kit-K0690) were used for 30 min, respectively. Subsequently, sections were incubated with Streptavidin-Horseradish Peroxidase (DAKOUniversal LSAB Kit-K0690) and binding sites of antibody were visualized with DAB, and washed in PBS. Nuclei were stained with Harry's haematoxylin, dehydrated through an increasing series of ethanol and cleared in xylene, then were mounted in entellan. The binding of antibody was evaluated by high-power microscopic examination.

Semi-quantitative and statistical analysis: The localisation of the endocrine islet types were analyzed from sections of caput, corpus and tail of all lobes. For the $10 \mathrm{X}$ magnification, the 100 square micrometre area was determined by means of a micrometer slide (almost, in $1 \mathrm{~mm}^{2}$ ). The each islet type was counted in 5 randomly selected microscopic areas at X 10 objective (in total, counted in area $5 \times 1 \mathrm{~mm}^{2}$ from each a serial section) and the arithmetic mean was scored semi-quantitatively (3). Mean \pm standard error values were calculated for each islets to determine the significance of inter-lobes differences. Each islet was analysed separately by using one-way analysis of variance (ANOVA). For determining differences among pancreatic lobes, the Duncan test was used (7). A $p$ value of $<0.05$ was considered to be significant.

\section{Results}

The pancreas of the falcons were located in a horizontal position adjacent to the duodenum; it was clarify divided into dorsal, ventral, and splenic lobes by septal formations composed of connective tissue (Figure 1). Pancreas sections stained with Mallory's triple modified by Crossman were demonstrated characteristic appearance of both exocrine and endocrine tissues in the falcons. Pyramidal-shaped acinar cells were determined that the basal cytoplasms were dark stain due to the presence of ER, whereas apical cytoplasms were acidophilic stain due to the presence of zymogene granules with triple stain (Figures 2A and 2B). Also, a few acinar cells were found within endocrine islets (Figure 2B). Centro-acinar cells were found frequently in the lumen of acinus (Figure 2A). The pancreatic ducts were consisted of intralobular ducts with squamous epithelium, interlobular and interlobar ducts with columnar epithelium. The large interlobar ducts were contained to gland similar crypts in the lamina propria and one or two layers of smooth muscle in tunica muscularis (Figure 3A). Furthermore, in the apical surface of columnar epithelial cells were identified a 


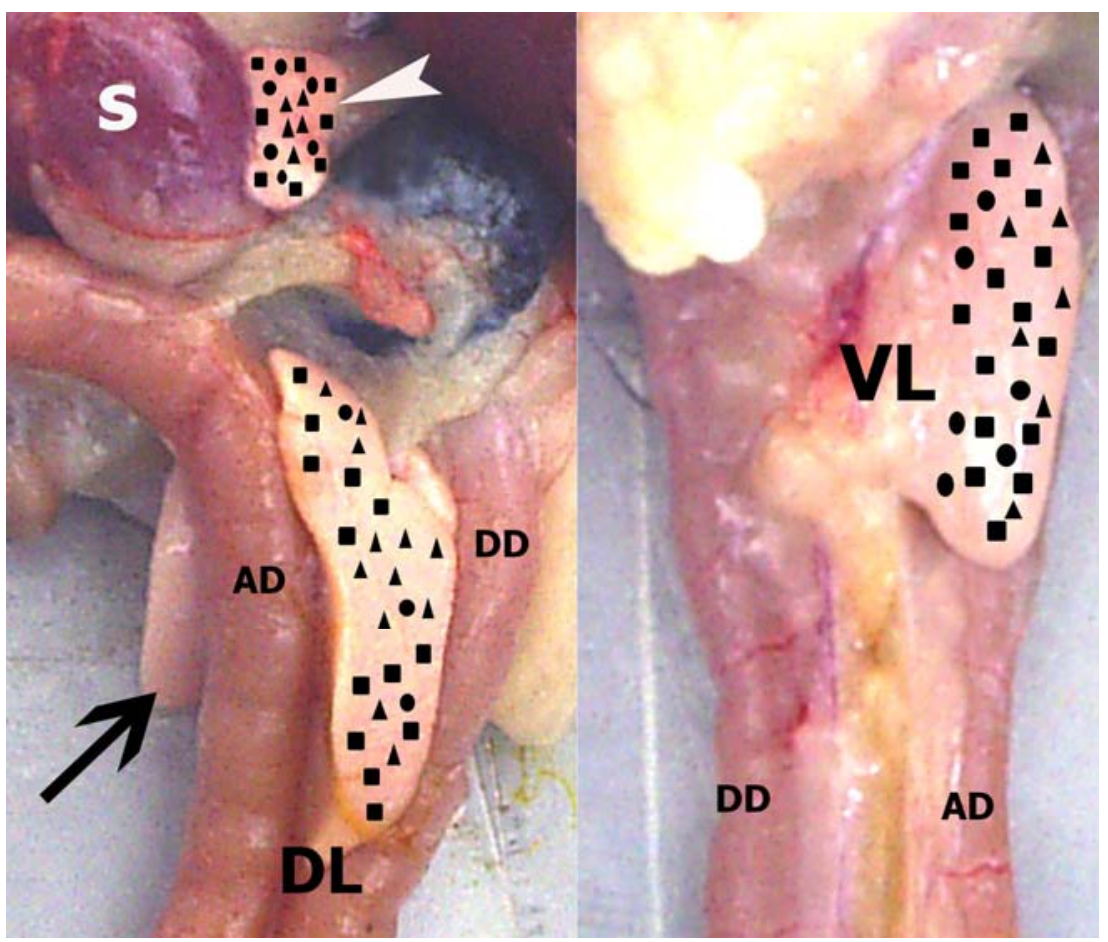

Figure 1. Anatomical position of falcon pancreas and distributions of the endocrine islets according to the caput, corpus and tail section of the lobes. Descendens duodeni (DD), ascendens duodeni (AD), dorsal lobe (DL), ventral lobe (VL, arrow), splenic lobe (arrow head), spleen (S), alpha islets (triangles), beta islets (squares), mixed islets (circles).

Şekil 1. Şahin pankreasının anatomik yapısı ve lobların baş, gövde, kuyruk bölümlerine göre endokrin adacıkların dağılımı. Desendens duodenum (DD), asendens duodenum (AD), dorsal lop (DL), ventral lop (VL, ok), dalak lobu (ok baş1), dalak (S), alfa adacıkları (üçgenler), beta adacıkalrı (kareler), miks adacıklar (daireler).

layer sulphated acidic mucosubstances by aldehyde fuchsin stain (Figure 3B). In the duodenum, bile ducts enter separately but at the same location as the 3 main pancreatic ducts.

Semi-quantitative analyze (in \%) of the alpha, beta and mixed islets according to the different lobes are shown in table 1, and distributions of the endocrine islets according to the caput, corpus and tail section of the lobes are shown in figure1. The falcon endocrine pancreas was containing round or irregular islets distributed throughout the pancreas that were comprised of alpha, beta and mixed islets $(34.78 \pm 2.18 \%, 47.83 \pm$ $4.71 \%$ and $17.39 \pm 5.32 \%$, respectively). The each three islets were determined in caput, corpus and tail region of the splenic lobe as well as in other lobes. Although beta and mixed islets were widespread as small clusters in all lobes, alpha islets were numerous in the splenic lobe, a few in other lobes as large clusters.

In sections stained with aldehyde fuchsine were presented yellowish-green alpha islets (Figure 4A), purple-violet beta islets (Figure 4B), and yellowish-green and purple-violet mixed islets (Figures 4B, 4C and 4D). In the streptavidin-biotin-peroxidase staining, insulin immunpositive cells were observed to be few in the both alpha islets (Figure 5A) and exocrine parenchyma (Figure 5B), but they were presented numerous in the centre of beta islets (Figure 5B) and in mixed islets (Figure 5C). Moreover, insulin immunpositive cells were presented rarely in between of the acinar cells in all lobes (Figure 5D) and numerously in the exocrine parenchyma neighbored to duodenum of dorsal and ventral lobes as one cell and/or 3-8 immunpositive cell groups (Figure 6).

Table 1. Proportions (in \%) of different islet types of the endocrine pancreas according to the lobes in falcons $(n=5)$. Results are expressed as mean \pm standard deviation.

Tablo 1. Şahinlerde farklı loblara göre endokrin pankreasın adacık tiplerinin $(\%)$ oranı $(n=5)$. Sonuçlar ortalama \pm standart sapmayı göstermektedir.

\begin{tabular}{lccc}
\hline Localisation & \multicolumn{3}{c}{ Islet types } \\
\cline { 2 - 4 } & $\alpha$ & $\beta$ & mixed \\
\hline $\begin{array}{l}\text { Proportion in all } \\
\text { pancreas }\end{array}$ & $34.78 \pm 2.18^{\mathrm{b}}$ & $47.83 \pm 4.71^{\mathrm{a}}$ & $17.39 \pm 5.32^{\mathrm{c}}$ \\
Repartition per & & & \\
lobe & & & \\
Dorsal lobe & $46.43 \pm 3.12^{\mathrm{Aa}}$ & $39.28 \pm 1.25^{\mathrm{Bb}}$ & $14.29 \pm 4.54^{\mathrm{Bc}}$ \\
Ventral lobe & $28.00 \pm 4.14^{\mathrm{Bb}}$ & $60.00 \pm 3.22^{\mathrm{Ac}}$ & $12.00 \pm 2.01^{\mathrm{Bc}}$ \\
Splenic lobe & $25.00 \pm 5.81^{\mathrm{Bc}}$ & $43.75 \pm 4.36^{\mathrm{Ba}}$ & $31.25 \pm 1.47^{\mathrm{Ab}}$ \\
\hline
\end{tabular}

Different superscripts $\mathrm{a}, \mathrm{b}, \mathrm{c}$ in the same line indicate significant differences between proportions of the different islet types in the whole pancreas and each pancreatic lobes.

Aynı satırdaki a, b, c harfleri pankreasın tamamında ve her pankreatik lobdaki farklı adacık tiplerinin oranı arasındaki önemliliği göstermektedir.

Different superscripts A,B,C in the same column indicate significant differences between proportions of the same islet type in the different pancreatic lobes.

Aynı sütundaki A, B, C harfleri farklı pankreatik loblardaki farklı adacık tiplerinin oranı arasındaki önemliliği göstermektedir. 

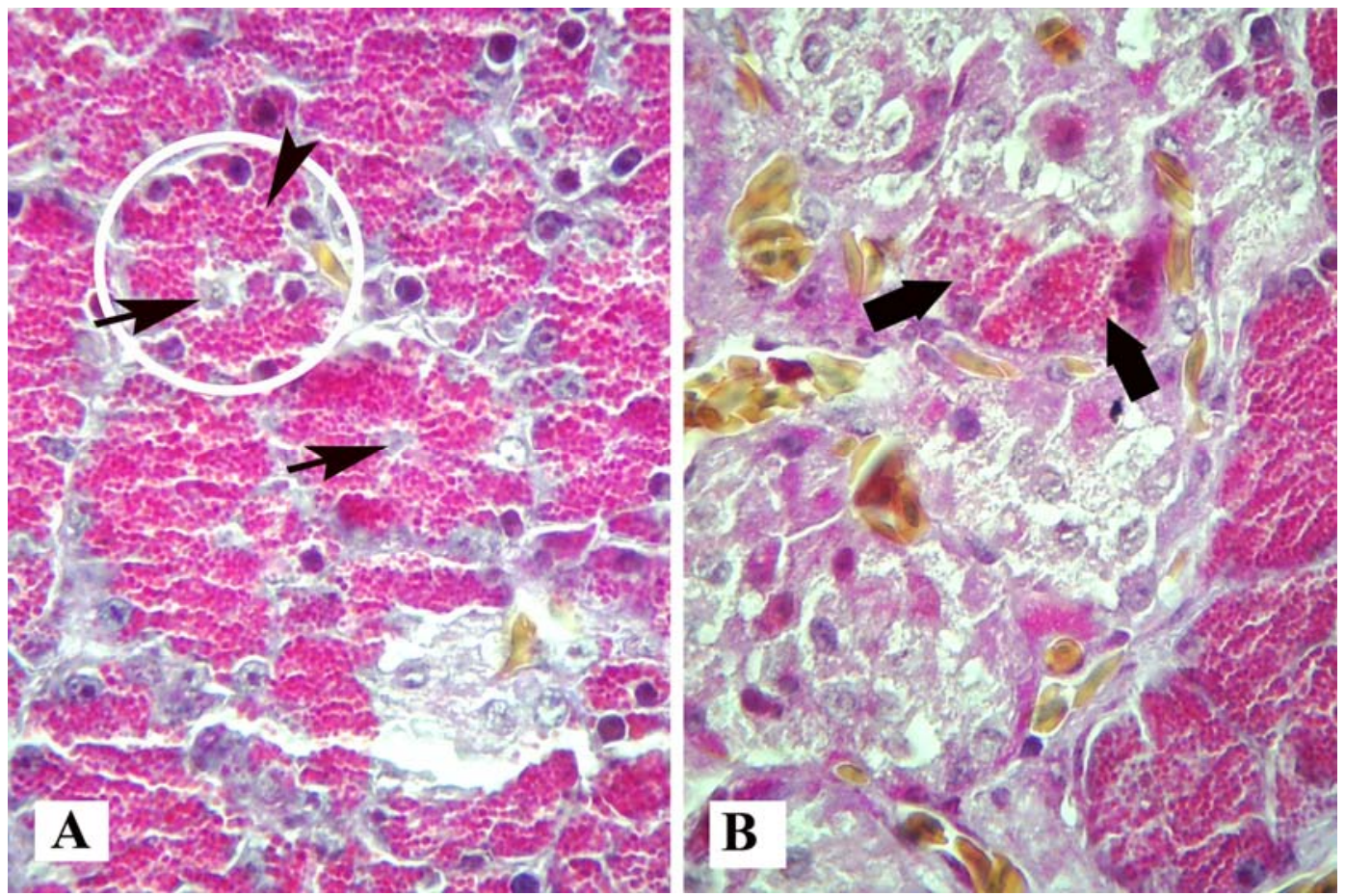

Figure 2. Micrograph of acinus cells, 2A: acinus (encircled), centro-acinar cells (arrows), zymogene granules (arrow head). 2B: acinar cells within islets (bold arrows). Triple stain. X 625.

Şekil 2. Asinus hücrelerinin mikroskobik görünümü. 2A: asinus (çember içine alınan), sentro-asiner hücreler (oklar), zimogen granüller (ok başı). 2B: adacık içerisindeki asiner hücreler (kalın oklar). Üçlü boyama. X 625.
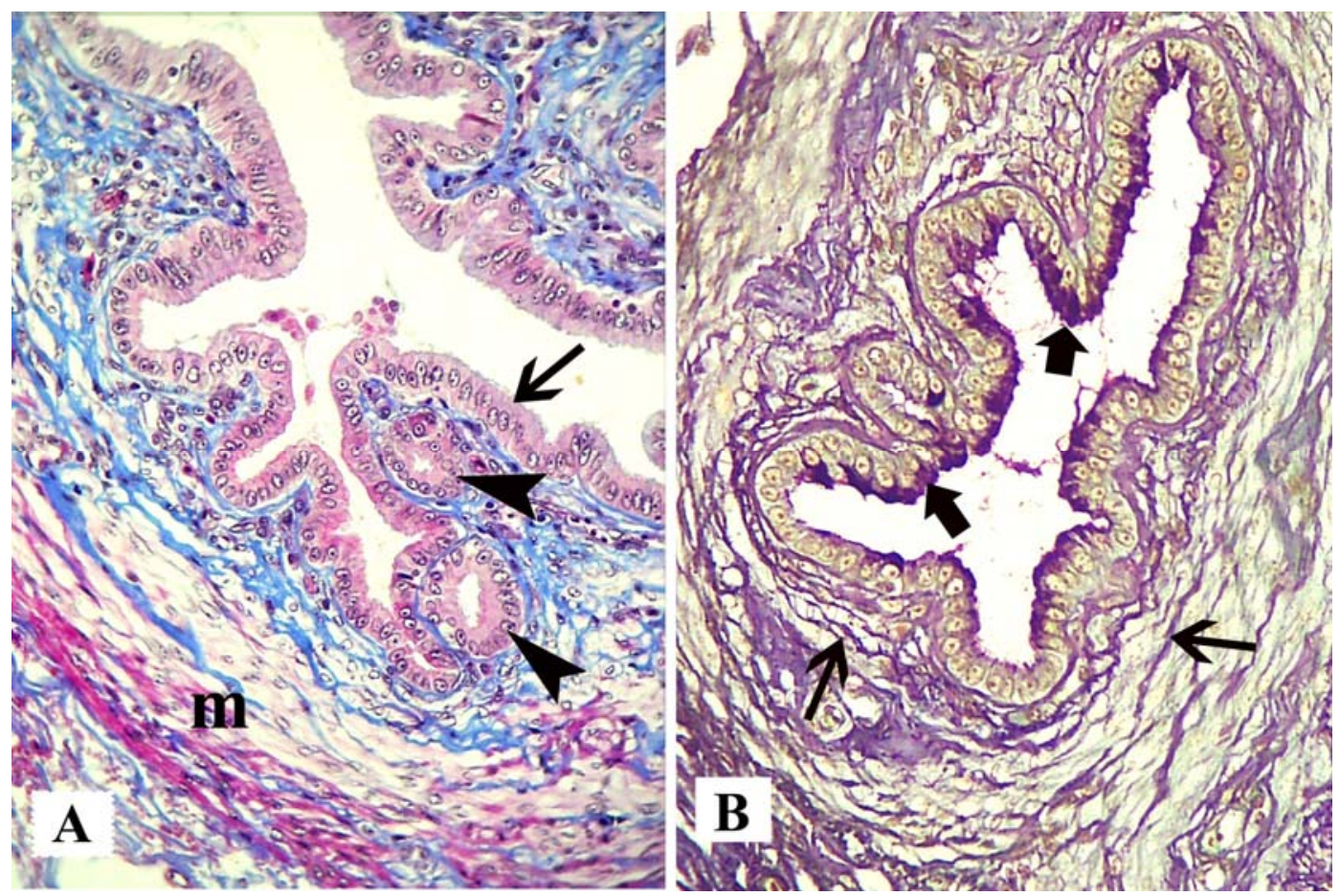

Figure 3. Micrograph of large pancreatic ducts. 3A: one layer columnar epithelium (arrow), gland similar to crypts (arrow heads), thick muscle layers (m).Triple stain. X 325. 3B: elastic fibres (arrows), sulphated acidic mucosubstance (bold arrows). AF stain. X 325.

Şekil 3. Büyük pankreatik kanalların mikroskobik görünümü. 3A: tek katlı prizmatik epitel (ok), bez benzeri kriptler (ok başları), kalın kas katmanı (m).Üçlü boyama. X 325. 3B: elastic iplikler (oklar), sülfatlı asidik mukosubstans (kalın oklar). AF boyama. X 325. 


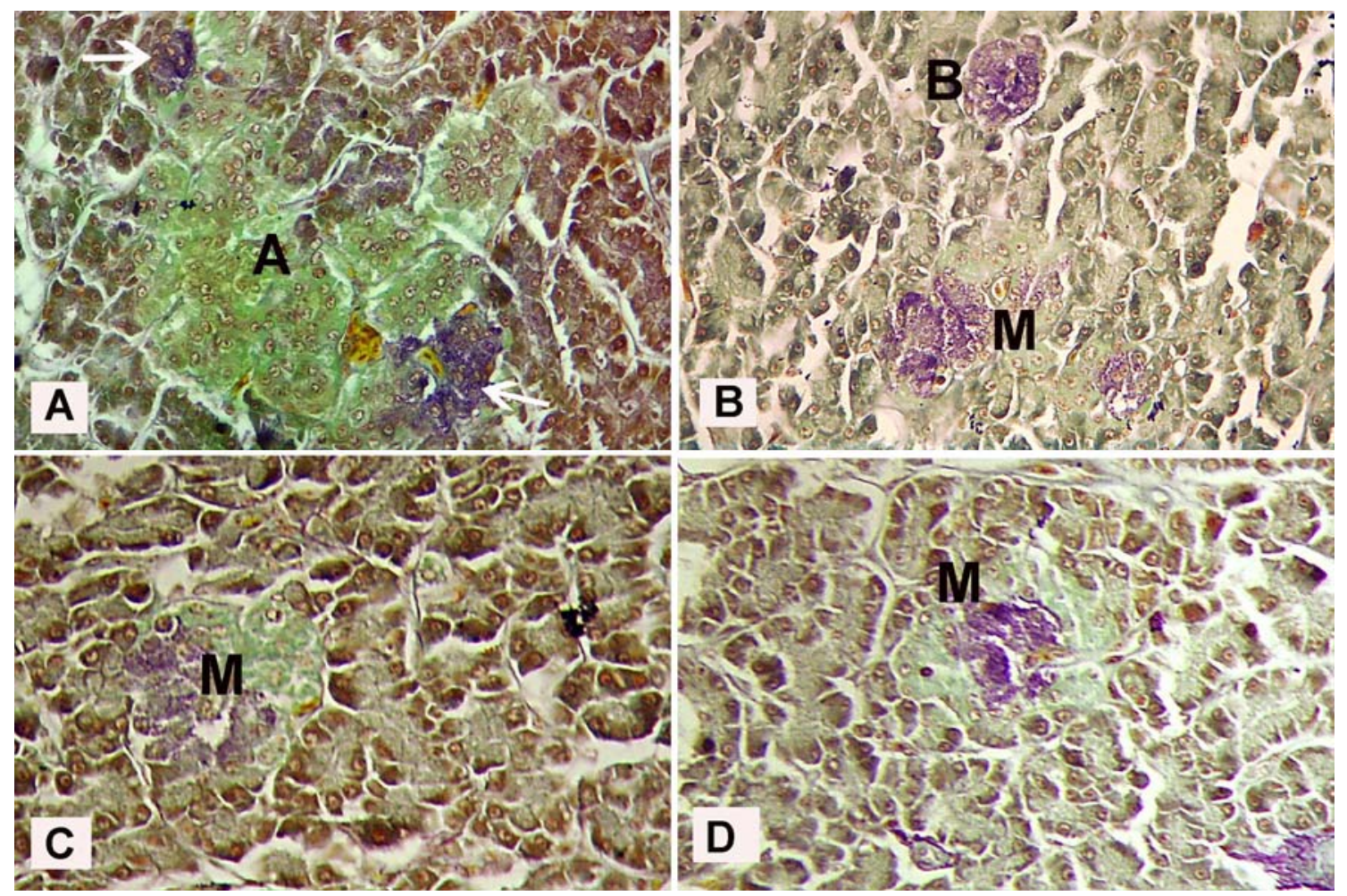

Figure 4. Identification of endocrine islets in falcons by histochemistry. Alpha islet (A), beta islet (B), mixed islet (M), beta cells in alpha islet (arrows). AF stain. X 325.

Şekil 4. Şahinlerde endokrin pankreasın histokimyasal belirlenmesi. Alfa adası (A), beta adası (B), miks adacık (M), alfa adasındaki beta hücreleri (oklar). AF boyama. X 325 .
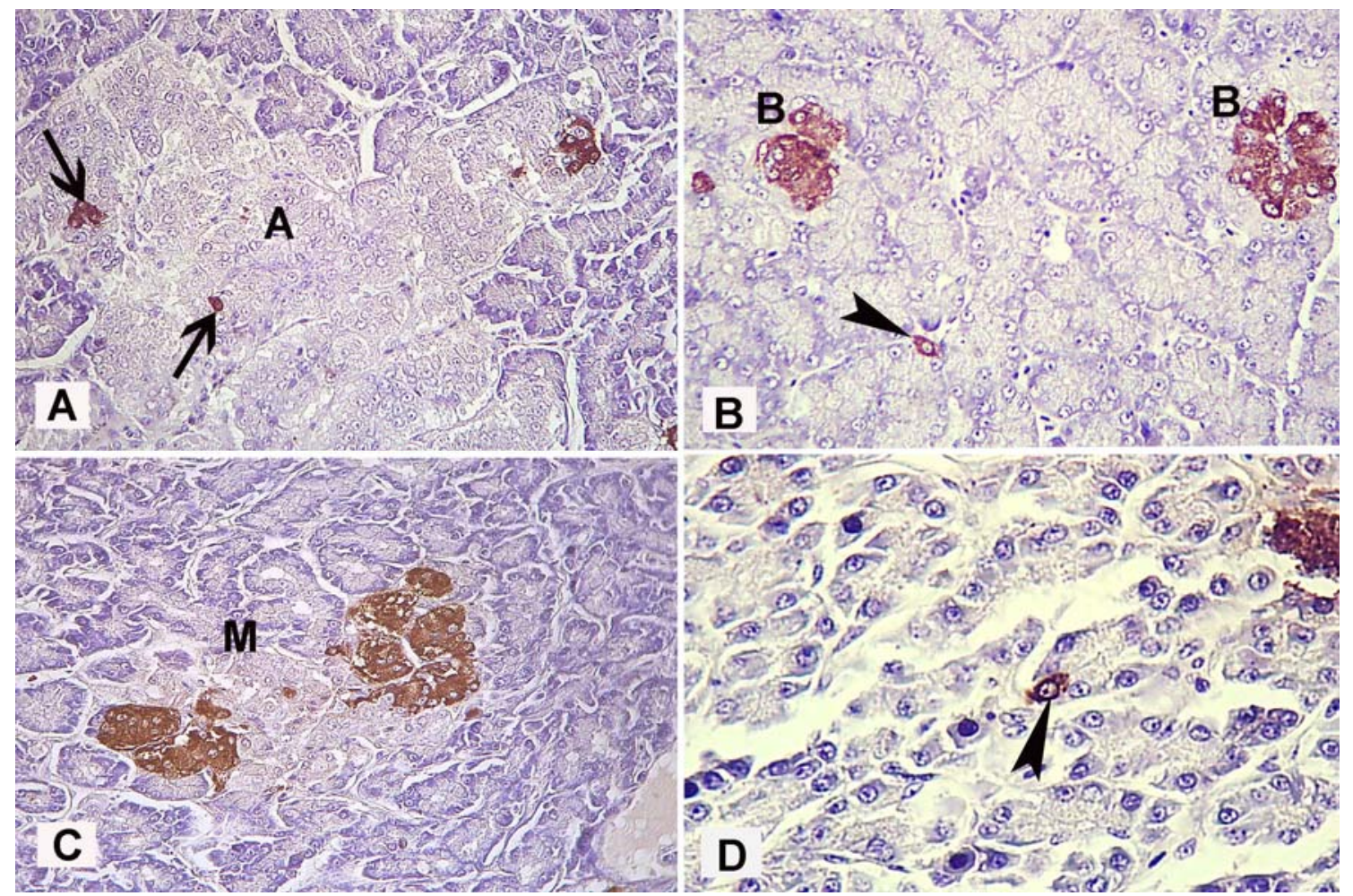

Figure 5. Micrograph of insulin immunpositive cells in endocrine islets. Alpha islet (A), beta islet (B), mixed islet (M), insulin immunpositive beta cells in alpha islet (arrows), insulin immunpositive beta cells within acinus (arrow heads). Strepteavidin-biotinperoxidase method. 5A, 5B, 5C: X 340, 5D: X 625.

Şekil 5. Endokrin adacıklardaki insulin immunpozitif hücrelerin mikroskobik görünümü. Alfa adası (A), beta adası (B), miks adacık (M), alfa adasında insülin immunpozitif beta hücreleri (oklar), asinus içerisinde insülin immunpozitif beta hücrekleri (ok başları). Streptavidin-biotin peroksidaz metodu. 5A, 5B, 5C: X 340, 5D: X 625. 


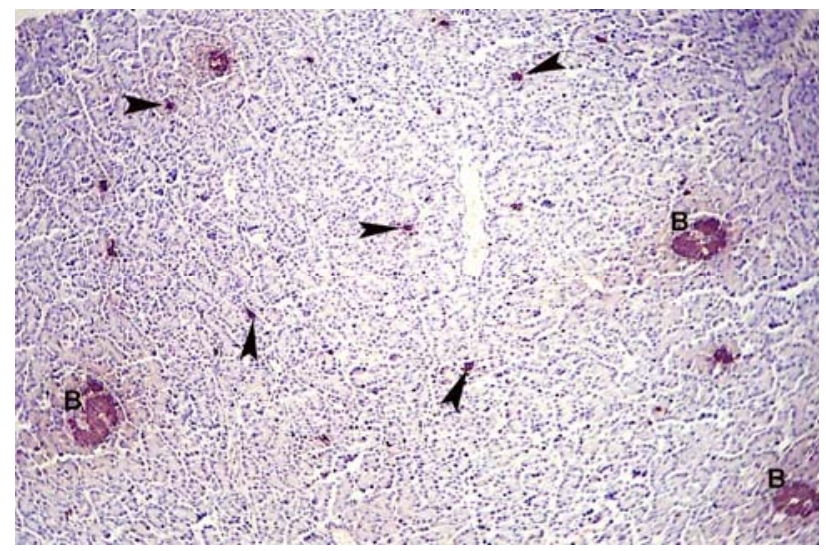

Figure 6. Insulin immunpositive beta cells in exocrine parenchyma (arrow heads), beta islets (B). Streptavidin-biotin peroxidase method. X 125.

Şekil 6. Ekzokrin paranşimadaki insulin immunpozitif beta hücreleri (ok başları), beta adacıkları (B). Streptavidin-biotin peroksidaz metodu. X 125.

\section{Discussion and Conclusion}

This study confirmed that the pancreas of falcons is comprised of dorsal, ventral and splenic lobes, like that of three lobed structures in ducks $(13,14,19)$, whereas it is four lobed structure in chickens (12) and geese (10), quails $(23,24)$. Moreover, falcons also have two dorsal pancreatic ducts and one ventral pancreatic duct that open separately into the duodenum at the same site of entrance of biliary ducts.

The exocrine pancreas is comprised of tubuloacinar glands, ducts, blood vessels and nerve fibres which are similar manner to the salivary glands. The tubulo-acinar glands are comprised of pyramid shaped exocrine secretory cells, which basal cytoplasm is rich from ER, and apical cytoplasm is filled with zymogene secretory granules (16). Pancreatic ducts are beginning with intercalated duct cells and continuing with intercalate, intralobular, interlobular and interlobar ducts lead into each other. They ducts are lined with flattened squamous, cuboidal, low columnar and long two layers columnar epithelial cells, respectively (8). In the lamina propria of large excretory ducts are reported to be found glands in cat, human (8) and geese (9). In this study, light microscopic showings of tubulo-acinar glands, ducts and centro-acinar cells were similar to researchers. However, a few acinar cells were found within endocrine islets, and in the lamina propria layers of mediate or large ducts were determined a few crypt similar to cat and human. Also, these crypts were composed mainly of tall columnar cells, but were not contained goblet, mucous or serous cells.

The pancreatic endocrine cells cannot be distinguished with haematoxylin and eosin staining. However, histochemical and immunohistochemical techniques are useful for demonstrate alpha, beta, D, and PP cells types. These are chrome alum haematoxylinphloxine for alpha and beta cells, Gomori's aldehyde fuchsin for beta cells (6), and Mallory's phosphotungstic acid haematoxylin, Grimelius argyrophil technique for alpha cells (1), in immunocytochemical techniques specific antisera are used against the glucagon, insulin, somatostatin and pancreatic polypeptide hormones produced by islet cell. In the falcons, the histochemical characteristics of the endocrine cells were similar to that of some other avian. In AF stain was identified that beta islets stained purple-violet, alpha islets stained yellowishgreen and mixed islets stained purple-violet and yellowish-green. Polak et al. (18), Salvi and Renda (21) have pointed out that mammalian-derived antibodies are giving cross- reaction with avian species, whereas some researchers have been demonstrating immune-positive reaction with rabbit anti-somatostatin in goose (10) and in young quails (24). In this study was succeed illustrates a positive and specific immunohistochemical localization of insulin using polyclonal guinea pig anti-swine insulin mammalian antibody in the falcon's each three lobes.

Amongst species, varieties of endocrine cells are different the in distribution and location in pancreatic islets. Alpha, beta, D and PP endocrine cells are mainly grouped into the islets of Langerhans in mammals (27), whereas endocrine islets are composed of large alpha islets, moderate or small beta islets $(12,20)$ and mixed islets in the aves $(14,24)$. The endocrine islets are most numerous in the tail region (splenic lobe) of the pancreas both mammalian and bird species (13). The alpha and beta islets are reported to be numerous in all lobes in ducks (19) and in the splenic and third lobes in chickens $(20,25)$, geese (10) and young quails (24). Rawdon and Larsson (20) are reported that the smaller beta islets are present in the dorsal and ventral lobes, Gülmez et al. (10) are pointed out that mixed islets are not found in geese pancreas, but in this study, beta islets were shown almost the same size in all of lobes, and mixed islets were determined clearly with both histochemical and immunohistochemical staining in pancreatic all lobes of falcons.

In the mammalian species, beta cells are to be found in the centre of the islets, and alpha cells are disorganized in the periphery of islets, whereas location of alpha and beta cells are opposite in horse (27). Alpha islets are comprised of many alpha cells, a few D cells (5), and seldom beta cells in chickens (26) and young quails (24). On the other hands, some authors have reported that alpha islets are composed of alpha, D and Type IV cells (23), and alpha, C, D and PP cells in adult quails (22). In the AF histochemical staining of this study, alpha islets were comprised of many alpha cells and a few beta cells. Moreover, immunohistochemical staining was examined that the insulin immunpositive cells were found in alpha islets as one and/or 3-8 cells group. The beta islets are comprised of numerous beta cells and a few D cells in avian species (5). Moreover, alpha cells are rarely present in the periphery of beta islets in geese (10) and quails $(23,24)$. In this study, beta islets found small cluster in 
all lobes that they were contained abundant insulin immunpositive beta cells. Some researchers have reported that periphery of endocrine islets contains acinar-islet cells in the chicken (15), intermediate endocrine-acinar cells are localized within endocrine islets (2) and insulin immunpositive cells are found among acinar cells in young quails (24). In this study was determined abundantly one by one and/or 2-3 cells group in exocrine parenchyma of the all pancreatic lobes. Furthermore, some insulin immunpositive cells were seen in between of acinus and acinar cells

In conclusion, endocrine and exocrine pancreas of falcons have revealed several differences among avian species. They have dorsal, ventral and splenic lobes, and three main excretory ducts. The endocrine pancreas is contained alpha, beta and mixed islets. The insulin immunpositive cells are located not only in beta islet but also other islets and exocrine parenchyma.

\section{References}

1. Bancroft JD, Cook HC (1984): Manual of Histological Techniques. 42-45, 71-73, 164-165. Churchill Livingstone Medical Division Longman Group Limited, UK.

2. Bertelli E, Bendayan M (1997): Intermediate endocrineacinar pancreatic cells in duct ligation conditions. Am J Physiol Cell Physiol, 273, 1641 - 1649.

3. Böck P. (1989): Romeis Microskopische Tecknik. 17. Aufl. Urban und Scwarzenberg. München.

4. Böck P, Moneim M, Egerbacher M (1997): Development of pancreas. Microsc Res Techn, 37, $374-383$.

5. Cowap J (1985): The first appearence of endocrine cells in the splenic lobe of the embriyonic chick pancreas. Gen Comp Endocrin, 60, 131 - 137.

6. Culling CFA, Allison RT, Barr WT (1985): Cellular Pathology Technique, pp.: 439. $4^{\text {th }}$ Ed., Butterworth \& Co. Ltd. London.

7. Duncan DB (1955): Multiple range and multiple $F$ test. Biometrics, 11, 1-2.

8. Egerbacher M, Böck P (1997): Morphology of the pancreatic duct system in mammals. Microsc Res Tech, 37, $407-17$

9. Gülmez N (2003): Are glands present in goose pancreatic ducts? A light microscope study. J Pancreas, 4, $125-128$.

10. Gülmez N, Kocamış H, Aslan Ş, Nazlı M (2004): Immunohistochemical distribution of cells containing insulin, glucagon and somatostatin in the goose (Anser anser) pancreas. Turk J Vet Anim Sci, 28, 403 - 407.

11. Hodges RD (1974): The Histology of the Fowl. $101-109$. Academic Press London, New York, San Francisco.

12. Ku SK, Lee JH, Lee HS (2000): An immunohistochemical study of the insulin-, glucagon- and somatostatinimmunoreactive cells in the developing pancreas of the chicken embryo. Tissue Cell, 32, $58-65$.

13. Liu JW, Evans H, Larsen P, Pan D, Xu SZ, Dong HC, Deng XB, Wan B, Gi T (1998): Gross anatomy of the pancreatic lobes and ducts in six breeds of domestic ducks and six species of wild ducks in china. Anat Histol Embryol, 27, 413 - 417.

14. Lucini C, Castaldo L, Lai O (1996): An immunohistochemical study of the endocrine pancreas of ducks. Eur J Histochem, 40, 45 - 52.
15. Mikami SI, Mutoh K (1977): Light- and electronmicroscopic studies of the pancreatic islet cells in the chicken under normal and experimental conditions. Cell Tissue Res, 180, 453 - 465.

16. Motta MP, Macchiarelli G, Nottola SA, Correr S (1997): Histology of the exocrine pancreas. Microsc Res Tech, 37, $384-398$.

17. Nagasao J, Sugiyama D, Yoshioka K, Amasaki H, An T, Yue Z, Mutoh K (2003): Morphological relationship between intercalated duct and pancreatic islet in streptozotocin and/or camostat mesilate administrations in the chicken. Anat Histol Embryol, 32, 89 - 93.

18. Polak JM, Pearse AGE, Adams C, Garaud JC (1974): Immunohistochemical and ultrastructural studies on the endocrine polypeptide (APUD) cells of the avian gastrointestinal tract. CMLS, 30, 564 - 567.

19. Rawdon BB (1998): Morphogenesis and differentiation of the avian endocrine pancreas, with particular reference to experimental studies on the chick embryo. Microsc Res Tech, 43, $292-305$.

20. Rawdon BB, Larsson LI (2000): Development of hormonal peptides and processing enzymes in the embryonic avian pancreas with special reference to colocalisation. Histochem Cell Biol, 114,105-112

21. Salvi E, Renda T (1986): Immunohistochemical studies on the ontogenesis of some endocrine cells in the chicken antrum and duodenum. Basic Appl Histochem, 30, 307-316.

22. Simsek N, Alabay B (2008): Light and electron microscopic examinations of the pancreas in quails (Coturnix coturnix japonica). Revue Méd. Vét, 159, 198-206.

23. Smith PH (1974): Pancreatic islets of the coturnix quail. A light and electron microscopic study with special reference to the islet organ of the splenic lobe. Anat Rec, 178, $567-585$.

24. Şimşek N, Özudoğru Z, Alabay B (2008): Immunohistochemical studies on the splenic lobe of the pancreas in young japanese quails (Coturnix c. japonica). Dtsch Tierärztl Wschr, 115, 189 - 193.

25. Tomita T, Doull V, Pollock HG, Kimmell JR (1985): Regional distribution of pancreatic polypeptide and other hormones in chicken pancreas: reciprocal relationship between pancreatic polypeptide and glucagon. Gen Comp Endoc, 58, $303-310$.

26. Watanabe T, Chikazawa H, Yamada J (1984): Catecholamine containing pancreatic islet cells of the domestic fowl. Light, fluorescence and electron microscopy, and immunohistochemistry. Cell Tissue Res, 237, $239-244$.

27. Yukawa M, Takeuchi T, Watanabe T, Kitamura $\mathbf{S}$ (1999): Proportions of various endocrine cells in the pancreatic islets of wood mice (Apodemus speciosus). Anat Histol Embryol, 28, 13 - 16.

Geliş tarihi: 26.06.2008 / Kabul tarihi: 30.12.2008
Address for correspondance:
Assist. Prof. Dr. Nejdet Şimşek
University of Atatürk, Faculty of Veterinary Medicine,
Department of Histology and Embryology
25700, Ilica Erzurum, Turkey
E.mail:nsimsek58@gmail.com \&
nsimsek-58@hotmail.com 